\title{
Psychological Approaches for the Integrative Care of Chronic Low Back Pain: A Systematic Review and Metanalysis
}

\author{
Giorgia Petrucci ${ }^{1}$, Giuseppe Francesco Papalia ${ }^{1}\left(\mathbb{D}\right.$, , Fabrizio Russo ${ }^{1, *(1)}$, Gianluca Vadalà ${ }^{1}\left(\mathbb{D}\right.$, Michela Piredda ${ }^{2}(\mathbb{D}$, \\ Maria Grazia De Marinis ${ }^{2}$, Rocco Papalia ${ }^{1}$ and Vincenzo Denaro ${ }^{1}$ \\ 1 Department of Orthopaedic and Trauma Surgery, Campus Bio-Medico University of Rome, 00128 Rome, Italy; \\ g.petrucci@unicampus.it (G.P.); g.papalia@unicampus.it (G.F.P.); g.vadala@unicampus.it (G.V.); \\ r.papalia@unicampus.it (R.P.); denaro@unicampus.it (V.D.) \\ 2 Research Unit Nursing Science, Campus Bio-Medico University of Rome, 00128 Rome, Italy; \\ m.piredda@unicampus.it (M.P.); m.demarinis@unicampus.it (M.G.D.M.) \\ * Correspondence: fabrizio.russo@unicampus.it
}

\section{check for}

updates

Citation: Petrucci, G.; Papalia, G.F.; Russo, F.; Vadalà, G.; Piredda, M.; De Marinis, M.G.; Papalia, R.; Denaro, V. Psychological Approaches for the Integrative Care of Chronic Low Back Pain: A Systematic Review and Metanalysis. Int. J. Environ. Res. Public Health 2022, 19, 60. https:// doi.org/10.3390/ijerph19010060

Academic Editor: Paul B.

Tchounwou

Received: 20 November 2021 Accepted: 14 December 2021 Published: 22 December 2021

Publisher's Note: MDPI stays neutral with regard to jurisdictional claims in published maps and institutional affiliations.

Copyright: (C) 2021 by the authors. Licensee MDPI, Basel, Switzerland. This article is an open access article distributed under the terms and conditions of the Creative Commons Attribution (CC BY) license (https:// creativecommons.org/licenses/by/ $4.0 /)$.

\begin{abstract}
Chronic low back pain (CLBP) is the most common cause of disability worldwide, affecting about $12 \%$ to $30 \%$ of the adult population. Psychological factors play an important role in the experience of pain, and may be predictive of pain persistence, disability, and long-term sick leave. The aim of this meta-analysis was to identify and to describe the most common psychological approaches used to treat patients who suffer from CLBP. A systematic search was performed on PubMed/MEDLINE and Cochrane Central. Overall, 16 studies with a total of 1058 patients were included in the analysis. Our results suggest that cognitive behavioral therapy (CBT) and mindfulnessbased stress reduction (MBSR) interventions are both associated with an improvement in terms of pain intensity and quality of life when singularly compared to usual care. Disability also improved in both groups when compared to usual care. Significant differences in fear-avoidance beliefs were noted in the CBT group compared to usual care. Therefore, psychological factors are related to and influence CLBP. It is crucial to develop curative approaches that take these variables into account. Our findings suggest that CBT and MBSR modify pain-related outcomes and that they could be implemented in clinical practice.
\end{abstract}

Keywords: low back pain; cognitive behavioral therapy; mindfulness-based stress reduction; depression; disability; fear-avoidance beliefs

\section{Introduction}

Chronic low back pain (CLBP) is the most common cause of disability worldwide [1,2], affecting about $12 \%$ to $30 \%$ of the adult population $[3,4]$. It is estimated that $50 \%$ to $80 \%$ of adults feel at least one episode of back pain during their lifetime [5]. Therefore, managing CLBP becomes crucial for both individuals and health care systems [1]. Chronic pain has a multidimensional nature and in addition to nociceptive and physiological aspects, it also includes aspects relating to the emotional and cognitive sphere [6]. Low back pain pathogenesis can also be diverse, including organic, non-specific etiology, and psychological causes [7,8]. Psychological factors play an important role in the experience of pain $[9,10]$, as patients with CLBP who experience anxiety tend to exacerbate the painful sensation and increase illness behavior [11], catastrophizing pain [12-14]. These factors can make the pain experience, as well as the mechanical and physiological processes, last longer $[15,16]$, causing physical and psychosocial disability [9]. In this regard, it has been shown that patients with CLBP suffering from depression experience higher levels of pain, functional disability, and lower levels of health-related quality of life (QoL) [16]. So, all psychological variables may be predictive of pain persistence, disability, long-term sick leave $[11,15]$, significantly influencing the quality of life perceived by patients. Therefore, it is crucial to assess and address the psychological sphere as much as the other aspects, designing a 
holistic and integrative framework to treat patients affected by LBP $[7,17]$. The American Pain Society (APS) published specific evidence-based guidelines for an interdisciplinary treatment and rehabilitation (defined as an integrated intervention with rehabilitation plus a psychological and/or social/occupational component) as a treatment option for patients with chronic LBP [18]. With the advancements in health psychology, several approaches were implemented in the care of patients with chronic pain. To our knowledge, there exist different systematic reviews in literature $[16,19-22]$ that analyze psychological approaches to treating patients who suffer from CLBP. These studies do not evaluate which approach is most used. Moreover, a comparison between different types of psychological approaches, in order to evaluate the effectiveness in terms of improvement of clinical outcomes, has not been performed. The objectives of this systematic review and meta-analysis are (1) to identify and to describe the most common psychological approaches used to treat patients who suffer from Chronic LBP, and (2) to study the effectiveness of these approaches in terms of reduction of pain, disability, fear-avoidance behaviors, anxiety, depression, and of increase in quality of life of patients with Chronic LBP.

\section{Materials and Methods}

This systematic review was performed in agreement with the Preferred Reporting Items for Systematic Reviews and Meta-Analysis (PRISMA) guidelines [23]. The protocol was previously registered on PROSPERO (registration number CRD42021255687). This review included only randomized clinical trials (RCTs) that assessed the effectiveness of the most common psychological approaches on quality of life (QoL), pain, disability and fear-avoidance behaviors in adult patients suffering from chronic low back pain (CLBP).

\subsection{Inclusion Criteria}

We included RCTs published in the last 25 years that included adult patients with CLBP; compared psychological interventions with either comparator (usual care such as health education, physical exercise, information package and waiting list); and assessed reduction of pain, disability, fear-avoidance behaviors, anxiety, depression, and increase in quality of life. Studies were excluded if they were not RCTs, if they analyzed acute or sub-acute low back pain and if they included back-surgery patients.

\subsection{Search Methods}

We performed a systematic literature search on the following databases: PubMed/ MEDLINE, Scopus and Cochrane Central. No language restrictions were set. The search strategy was checked by three reviewers (G.P., G.F.P. and F.R.). We developed a specific question defining the intervention, the population, and outcomes to analyze (according with PICO method).

PICO methods. Definition of elements.

- Population: the reference population included not hospitalized patients suffering from chronic low back pain. The patients included should be at least 18 years old, and they did not have to undergo surgery.

- Interventions: Selected psychological approaches

- Comparison Intervention: usual care, education program, supportive care, physical exercise, physiotherapy and waiting list

- Outcomes: pain, disability, fear-avoidance, anxiety and depression reduction and the improvement of quality of life

The search string included the following keywords (both Mesh and free-terms in PubMed/MEDLINE): Low back pain OR "Low back pain *" OR lumbago OR "lower back pain" OR "lower back pain *" OR "Low Back Ache" OR "Low Back Ache *" OR "Low Backache" OR "Low Backache *"; cognitive behavioral therapy OR "behavioral treatment" OR "behavior treatment" OR "behavior therapy" OR "cognitive behavior treatment" OR "cognitive treatment" OR "cognitive therapy", Mindfulness OR Meditation OR "mindfulness meditation", "operant behavioral therapy", hypnotism OR hypnoanalysis 
OR hypnotherapy, "acceptance and commitment therapy". The reference lists of the included RCTs were examined to choose additional studies for inclusion. After removing duplicates, two reviewers (G.P. and G.F.P.) independently analyzed the abstracts. Conflicts of opinion were solved discussing with a third reviewer (F.R.). In the end, the full texts were read and checked by two reviewers (G.P. and G.F.P.), choosing the studies to include in the review and meta-analysis.

\subsection{Data Collection, Analysis, and Outcomes}

Two authors (G.P. and G.F.P.) independently extracted the following data from the studies selected: authors, year of publication, country, sample size, patients' age and sex, intervention (s) in the experimental and in the control group, follow-up period, outcomes analyzed, tools used and conclusions.

\subsection{Risk of Bias Assessment}

Two independent reviewers (G.P. and G.F.P.) evaluated the risk of bias of the included RCTs using the Cochrane risk-of-bias tool [24]. Possible differences in the assessment were checked by a third reviewer (F.R.). Each item was classified with a low, unclear, or high risk of bias. Thus, the studies present low risk of bias in case of six or seven domains at low risk of bias, unclear risk of bias in presence of four or five domains at low risk of bias, and high risk of bias if fewer than four domains were reported at low risk of bias.

\subsection{Statistical Analysis}

A meta-analysis was produced by Review Manager (RevMan) software Version 5.4.1. Pain, disability, quality of life, depression and fear-avoidance beliefs were assessed between CBT, MBRS and control groups as continuous outcomes. In presence of different scores, the relative outcome was presented as standard mean difference (SMD) with $95 \%$ confidence intervals, while we adopted mean difference (MD) for the outcomes assessed by the same score. Instead, days without pain was calculated as a dichotomous outcome using odds ratio (OR) with 95\% confidence intervals. The evaluation of the samples' weight for this outcome was assessed by the mean value of days without pain per number of patients as events and the number of patients per number of weeks of follow-up as total. The $\mathrm{I}^{2}$ test was adopted to check the heterogeneity of studies included. In case of low heterogeneity $\left(\mathrm{I}^{2}<55 \%\right)$, a fixed-effect model was used, otherwise, we adopted a random-effect model. The statistical significance of the results was set at $p<0.05$.

\section{Results}

\subsection{Results of the Literature Search}

The literature search yielded 3277 articles. After removal of duplicates, the reading of titles and abstracts led to 48 eligible papers. All 48 full-texts were read. Afterwards, 32 studies were eliminated for these reasons: patients who suffered from acute pain $(n=8)$, patients who suffered from sub-acute low back pain $(n=7)$, not reporting selected outcomes $(n=5)$, back surgery patients $(n=5)$, inpatients $(n=4)$, pediatric patients $(n=2)$, and hypochondriacal patients $(n=1)$. At the end of selection, 16 RCTs were included in the systematic review and meta-analysis (Figure 1 ). 


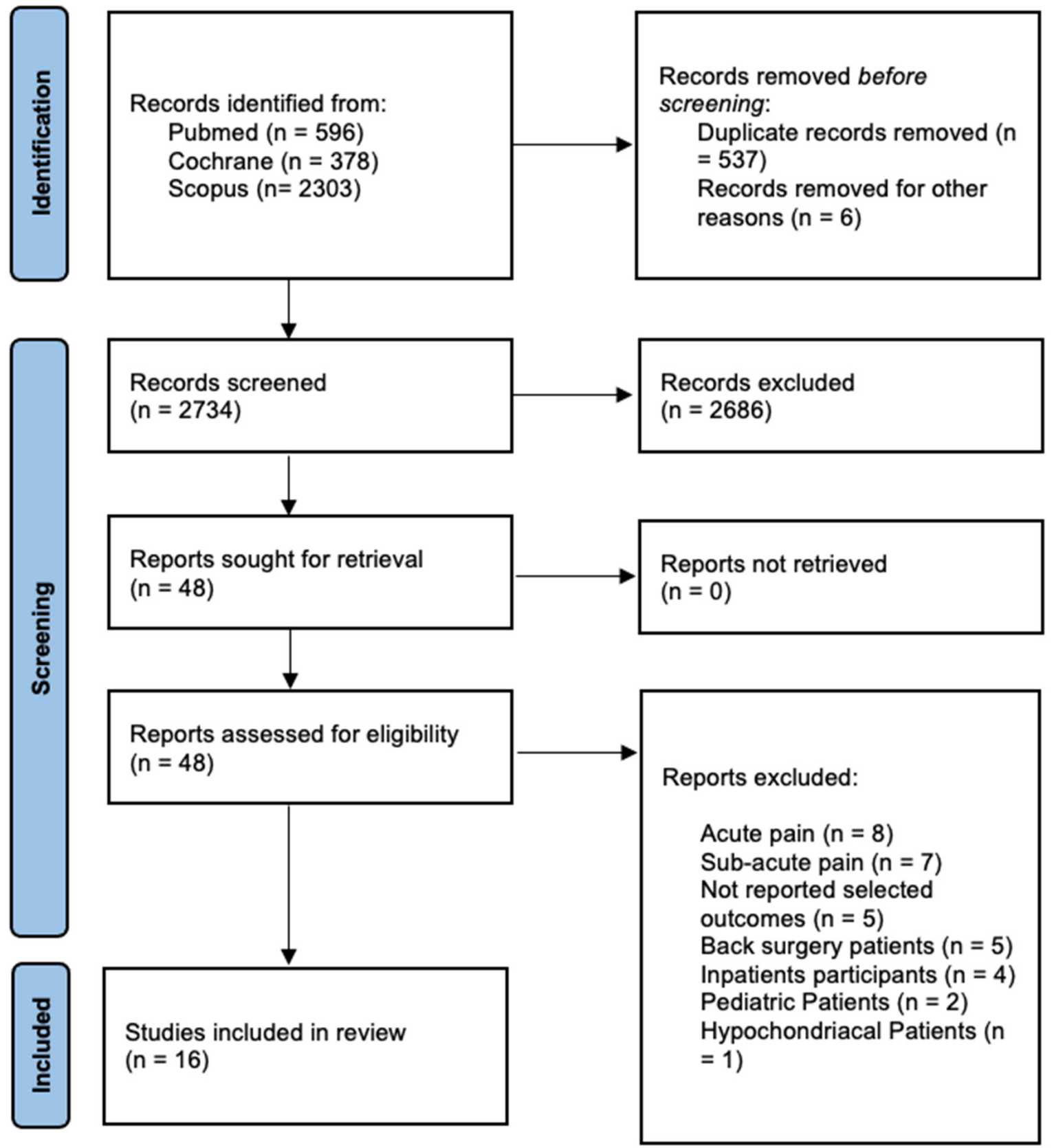

Figure 1. Preferred reporting items for systematic review and meta-analysis (PRISMA 2020).

\subsection{Demographic Data}

The total sample consisted of 2038 adults with CLBP reviewed-1058 were in the intervention group and 980 were in the control group. Most studies were published in the USA $(n=8 ; 50 \%)$, two studies were published in UK $(12.5 \%)$ and Germany $(12.5 \%)$, one study was published in Italy (6.25\%), in The Netherlands (6.25\%), in Pakistan (6.25\%) and in Sweden $(6.25 \%)$. The age of the patients ranged from 40.7 to 78 years in the experimental groups, and from 40.5 to 75.6 in the control groups. The percentage of women in the studies ranged from $13 \%$ to $80 \%$ in the intervention groups and from $6 \%$ to $87 \%$ in the control groups. In Table 1 the main characteristics of included studies and samples are reported. 
Table 1. Main characteristics of the included studies and samples.

\begin{tabular}{|c|c|c|c|c|c|c|c|c|}
\hline \multirow[t]{2}{*}{ Author } & \multirow[t]{2}{*}{ Year } & \multirow[t]{2}{*}{ Country } & \multicolumn{3}{|c|}{ Study Group } & \multicolumn{3}{|c|}{ Control Group } \\
\hline & & & N. & Age & Sex & N. & Age (Years) & Sex \\
\hline \multirow{2}{*}{ Cherkin et al. } & \multirow{2}{*}{2016} & \multirow{2}{*}{ USA } & 116 & $50 \pm 11.9$ & $\begin{array}{l}71 \% \mathrm{~F} \\
29 \% \mathrm{M}\end{array}$ & \multirow{2}{*}{113} & \multirow{2}{*}{$48.9 \pm 12.5$} & \multirow{2}{*}{$\begin{array}{c}87 \% \mathrm{~F} \\
13 \% \mathrm{M}\end{array}$} \\
\hline & & & 112 & $49.1 \pm 12.6$ & $\begin{array}{c}66 \% \mathrm{~F} \\
34 \% \mathrm{M}\end{array}$ & & & \\
\hline Monticone et al. & 2013 & Italy & 45 & $49 \pm 8$ & $\begin{array}{c}60 \% \mathrm{~F} \\
40 \% \mathrm{M}\end{array}$ & 45 & $49.7 \pm 7$ & $\begin{array}{c}55 \% \mathrm{~F} \\
45 \% \mathrm{M}\end{array}$ \\
\hline Johnson et al. & 2007 & UK & 116 & $47.3 \pm 10.9$ & $\begin{array}{c}61 \% \mathrm{~F} \\
39 \% \mathrm{M}\end{array}$ & 118 & $48.5 \pm 11.4$ & $\begin{array}{l}58 \% \mathrm{~F} \\
42 \% \mathrm{M}\end{array}$ \\
\hline \multirow{2}{*}{ Smeets et al. } & \multirow{2}{*}{2006} & \multirow{2}{*}{$\begin{array}{l}\text { The } \\
\text { Netherlands }\end{array}$} & 58 & $42.5 \pm 9.7$ & $\begin{array}{l}58.6 \% \mathrm{~F} \\
41.4 \% \mathrm{M}\end{array}$ & 53 & $42.7 \pm 9.1$ & $\begin{array}{c}41.5 \% \mathrm{~F} \\
58.5 \% \mathrm{M}\end{array}$ \\
\hline & & & 61 & $40.7 \pm 10.1$ & $\begin{array}{l}37.7 \% \mathrm{~F} \\
62.3 \% \mathrm{M}\end{array}$ & 51 & $40.5 \pm 11.2$ & $\begin{array}{l}37.3 \% \mathrm{~F} \\
62.7 \% \mathrm{M}\end{array}$ \\
\hline Rutledge et al. & 2018 & USA & 30 & $62.5 \pm 11.3$ & $\begin{array}{c}13 \% \mathrm{~F} \\
87 \% \mathrm{M}\end{array}$ & 31 & $64.3 \pm 12.7$ & $\begin{array}{c}6 \% \mathrm{~F} \\
92 \% \mathrm{M}\end{array}$ \\
\hline Rutledge et al. & 2018 & USA & 33 & $54 \pm 14.8$ & $\begin{array}{l}37.5 \% \mathrm{~F} \\
62.5 \% \mathrm{M} \\
\end{array}$ & 33 & $52.6 \pm 12.5$ & $\begin{array}{l}39.4 \% \mathrm{~F} \\
60.6 \% \mathrm{M}\end{array}$ \\
\hline Linden et al. & 2014 & Germany & 53 & $50.4 \pm 6.9$ & $\begin{array}{c}68 \% \mathrm{~F} \\
32 \% \mathrm{M}\end{array}$ & 50 & $49.7 \pm 7$ & $\begin{array}{c}68 \% \mathrm{~F} \\
32 \% \mathrm{M}\end{array}$ \\
\hline Khan et al. & 2016 & Pakistan & 27 & $39.61 \pm 5.3$ & $\begin{array}{l}54 \% \mathrm{~F} \\
46 \% \mathrm{M}\end{array}$ & 27 & $39.61 \pm 5.3$ & $\begin{array}{l}54 \% \mathrm{~F} \\
46 \% \mathrm{M}\end{array}$ \\
\hline Pincus et al. & 2015 & UK & 45 & $43.7 \pm 16.3$ & $\begin{array}{c}60 \% \mathrm{~F} \\
40 \% \mathrm{M}\end{array}$ & 44 & $45.4 \pm 15.8$ & $\begin{array}{l}38.6 \% \mathrm{~F} \\
61.4 \% \mathrm{M}\end{array}$ \\
\hline Basler et al. & 1997 & Germany & 36 & $49.3 \pm 9.7$ & $\begin{array}{l}75.6 \% \mathrm{~F} \\
24.4 \% \mathrm{M}\end{array}$ & 40 & $49.3 \pm 9.7$ & $\begin{array}{l}75.6 \% \mathrm{~F} \\
24.4 \% \mathrm{M} \\
\end{array}$ \\
\hline Jinton et al & 2000 & Sureden & 107 & 44 & $70 \% \mathrm{~F}$ & 70 & 45 & $\begin{array}{l}71 \% \mathrm{~F} \\
29 \% \mathrm{M}\end{array}$ \\
\hline Linton et al. & 2000 & Sweden & 107 & 44 & $30 \% \mathrm{M}$ & 66 & 44 & $\begin{array}{c}74 \% \mathrm{~F} \\
26 \% \mathrm{M}\end{array}$ \\
\hline Zgierska et al. & 2016 & USA & 21 & $51.8 \pm 9.7$ & $\begin{array}{l}80 \% \mathrm{~F} \\
20 \% \mathrm{M}\end{array}$ & 14 & $51.8 \pm 9.7$ & $\begin{array}{c}80 \% \mathrm{~F} \\
20 \% \mathrm{M}\end{array}$ \\
\hline Morone et al. & .2008 & USA & 19 & $74.1 \pm 6.1$ & $\begin{array}{l}53 \% \mathrm{~F} \\
47 \% \mathrm{M} \\
\end{array}$ & 18 & $75.6 \pm 5$ & $\begin{array}{c}61 \% \mathrm{~F} \\
39 \% \mathrm{M} \\
\end{array}$ \\
\hline Morone et al. & 2009 & USA & 16 & $78 \pm 7.1$ & $\begin{array}{c}69 \% \mathrm{~F} \\
31 \% \mathrm{M}\end{array}$ & 19 & $73 \pm 6.2$ & $\begin{array}{l}58 \% \mathrm{~F} \\
42 \% \mathrm{M}\end{array}$ \\
\hline Morone et al. & 2016 & USA & 140 & $75 \pm 7.2$ & $\begin{array}{c}66 \% \mathrm{~F} \\
34 \% \mathrm{M}\end{array}$ & 142 & $74 \pm 6.0$ & $\begin{array}{c}66 \% \mathrm{~F} \\
34 \% \mathrm{M}\end{array}$ \\
\hline Dаvet al & 2010 & ISA & 23 & 0 & $61 \% \mathrm{~F}$ & 23 & $48.1 \pm 16.1$ & $\begin{array}{l}52 \% \mathrm{~F} \\
48 \% \mathrm{M}\end{array}$ \\
\hline Day et di. & 2019 & USA & 23 & $49.9 \pm 11.9$ & $39 \% \mathrm{M}$ & 23 & $54.3 \pm 14.9$ & $\begin{array}{l}44 \% \mathrm{~F} \\
56 \% \mathrm{M}\end{array}$ \\
\hline
\end{tabular}




\subsection{Type of Interventions}

The psychological approaches most used are the cognitive behavioral therapy (CBT) and mindfulness-based stress reduction (MBSR). CBT was evaluated in eleven studies, while the remaining three studies [25-27] examined MBSR. Two studies evaluated both CBT and MBSR $[9,28]$ versus usual care (Table 2). The mean follow-up was 7.8 months and ranged from 3 weeks to 15 months.

\subsection{Clinical Outcome Data}

The outcomes were analyzed by different tools. Disability was assessed using the Roland and Morris Disability Questionnaire (RMDQ) in 11 studies [9,13,26,27,29-34], the Oswestry Disability Index (ODI) in one study [35], the pain-related disability (PRD) in one study [36], the Dusseldorf disability scale in one study [37], and the PROMIS—physical function in one study [28]. Intensity of pain was assessed using the Numeric Rating Scale (NRS) in six studies [27-31,37], the Visual Analogue Scale (VAS) in four studies [12,31,35,37], the Brief Pain Inventory (BPI) in two studies [34,35], and the McGill pain Questionnaire Short Form and SF-36 pain scale in two studies [25,26]. Quality of life was assessed using the Short-Form Health Survey (SF-36) in five studies [25-27,29,34], the EQ-5D in two studies [32,34], and the Short Form Health Survey (SF-12) in one study [9]. Fearavoidance behaviors were assessed using the Fear-Avoidance Belief Questionnaire (FABQ) in two studies [36,38], and the Tampa Scale of Kinesiophobia (TSK) in two studies [29,34]. Psychological disorders were assessed using the Generalized Anxiety Disorder 2-item (GAD-2) in three studies [8,33,37], the Personal Health Questionnaire Depression Scale (PHQ-8) in one study [9], the Hospital Anxiety and Depression Scale (HADS) in one study [34], the Beck's Depression Inventory (BDI) in two studies [13,31] and the PROMISdepression in one study [28].

\subsection{Methodological Evaluation}

After the application of the Cochrane risk-of-bias tool, nine studies (56\%) were at moderate risk of bias, four studies (25\%) were at low risk of bias and three studies were determined to be at high risk of bias (Table 3). 
Table 2. Clinical results of the included studies.

\begin{tabular}{|c|c|c|c|c|c|}
\hline Study & Intervention (s) & Control & Follow-Up & Outcomes (Tool) & Conclusion \\
\hline Cherkin et al., 2016 & $\begin{array}{l}\text { Mindfulness: body scan, yoga, } \\
\text { meditation, for } 8 \text { weeks. } \\
\text { CBT: education about chronic pain, } \\
\text { relationships between thoughts } \\
\text { and emotional and physical } \\
\text { reactions, sleep hygiene, setting } \\
\text { and working toward behavioral } \\
\text { goals, relaxation skills, activity } \\
\text { pacing, and pain-coping strategies, } \\
\text { for } 8 \text { weeks }\end{array}$ & $\begin{array}{l}\text { Usual care (whatever care } \\
\text { participants received) }\end{array}$ & 12 months & $\begin{array}{l}\text { Disability (RMDQ) } \\
\text { QoL (SF-12) } \\
\text { Depression (PHQ-8) } \\
\text { Anxiety (GAD-2) }\end{array}$ & $\begin{array}{l}\text { Among adults with CLBP, treatment } \\
\text { with MBSR or CBT, compared with } \\
\text { usual care, resulted in greater } \\
\text { improvement in back pain and } \\
\text { functional limitations at } 26 \text { weeks, } \\
\text { with no significant differences in } \\
\text { outcomes between MBSR and CBT }\end{array}$ \\
\hline Monticone et al., 2013 & $\begin{array}{l}\text { CBT: intervention to modify fear of } \\
\text { movement beliefs, catastrophizing } \\
\text { thinking, and negative feelings, } \\
\text { and ensuring gradual reactions to } \\
\text { illness behaviors, for } 5 \text { weeks }\end{array}$ & $\begin{array}{c}\text { Active and passive mobilizations } \\
\text { of the spine, and exercises aimed } \\
\text { at stretching and strengthening } \\
\text { muscles, and improving postural } \\
\text { control, for } 5 \text { weeks }\end{array}$ & 12 months & $\begin{array}{c}\text { Disability (RMDQ) } \\
\text { Pain (NRS) } \\
\text { QOL (SF-36) } \\
\text { Fear advoidance behaviours } \\
\text { (TSK) }\end{array}$ & $\begin{array}{l}\text { The long-lasting multidisciplinary } \\
\text { program was superior to the exercise } \\
\text { program in reducing disability, fear- } \\
\text { avoidance beliefs and pain, and } \\
\text { enhancing the quality of life of patients } \\
\text { with chronic low back pain. The effects } \\
\text { were clinically tangible and lasted for } \\
\text { at least } 1 \text { year after the intervention } \\
\text { ended. }\end{array}$ \\
\hline Johnson et al., 2007 & $\begin{array}{l}\text { CBT: educational pack containing a } \\
\text { booklet and audio-cassette }+ \\
\text { problem solving, pacing and } \\
\text { regulation of activity, challenging } \\
\text { distorted cognitions about activity } \\
\text { and harm, for } 6 \text { week }\end{array}$ & $\begin{array}{l}\text { Educational pack containing a } \\
\text { booklet and audio-cassette }+ \\
\text { usual care for } 6 \text { weeks }\end{array}$ & 15 months & $\begin{array}{l}\text { Pain (VAS) } \\
\text { Disability (RMDQ) } \\
\text { QoL (EQ-5D) }\end{array}$ & $\begin{array}{l}\text { CBT intervention program produces } \\
\text { only modest effects in reducing LBP } \\
\text { and disability over a 1-year period. }\end{array}$ \\
\hline
\end{tabular}


Table 2. Cont.

\begin{tabular}{|c|c|c|c|c|c|}
\hline Study & Intervention (s) & Control & Follow-Up & Outcomes (Tool) & Conclusion \\
\hline Smeets et al., 2006 & $\begin{array}{l}\text { CBT: operant behavioral graded } \\
\text { activity training and problem } \\
\text { solving training } \\
\text { Active Physical Treatment (APT): } \\
\text { aerobic training, and three } \\
\text { dynamic static strengthening } \\
\text { exercises for } 4 \text { weeks } \\
\text { Combined Treatment (CT): CBT + } \\
\text { APT }\end{array}$ & Waiting List (WL) for 10 weeks & 12 months & $\begin{array}{l}\text { Disability (RMDQ) } \\
\text { Pain (VAS) } \\
\text { Depression (BDI) }\end{array}$ & $\begin{array}{l}\text { CBT are as effective in reducing the } \\
\text { subjective experienced level of } \\
\text { functioning }\end{array}$ \\
\hline Rutledge et al., 2018 & $\begin{array}{l}\text { CBT: to provide core educational } \\
\text { information, guide patients' } \\
\text { learning and skills development, } \\
\text { and structure self-monitoring } \\
\text { exercises for the respective session, } \\
\text { for } 8 \text { weeks }\end{array}$ & $\begin{array}{c}\text { Supportive Care: } \\
\text { - Education by distribution of a } \\
\text { standard text } \\
\text { - Active Listening by the therapist } \\
\text { to participant's concerns } \\
\text { - Supportive care following } \\
\text { Rogerian principles }\end{array}$ & 12 months & $\begin{array}{l}\text { Disability (RMDQ) } \\
\text { Pain (NRS) } \\
\text { Depression (BDI) }\end{array}$ & $\begin{array}{l}\text { No evidence of meaningful effect size } \\
\text { differences between the treatments. }\end{array}$ \\
\hline Rutledgeet al., 2018 & $\begin{array}{l}\text { CBT: managing pain, managing } \\
\text { stress, thinking differently, } \\
\text { assertive communication, setting } \\
\text { goals for } 8 \text { weeks }\end{array}$ & $\begin{array}{c}\text { Supportive Care: } \\
\text { - Education by distribution of a } \\
\text { standard text } \\
\text { - Active Listening by the therapist } \\
\text { to participant's concerns } \\
\text { - Supportive care following } \\
\text { Rogerian principles }\end{array}$ & 12 months & $\begin{array}{l}\text { Disability (RMDQ) } \\
\text { Pain (NRS) }\end{array}$ & $\begin{array}{l}\text { CBT versus SC therapy demonstrated } \\
\text { statistically significant and comparable } \\
\text { patterns of improved outcomes on } \\
\text { measures of back pain disability, pain } \\
\text { severity, and self- rated improvement. }\end{array}$ \\
\hline
\end{tabular}


Table 2. Cont.

\begin{tabular}{|c|c|c|c|c|c|}
\hline Study & Intervention (s) & Control & Follow-Up & Outcomes (Tool) & Conclusion \\
\hline Linden et al., 2014 & $\begin{array}{l}\text { general orthopedic inpatient } \\
\text { treatment + therapy in reference to } \\
\text { the GRIP and the pain and illness } \\
\text { management program from } \\
\text { Geissner at al. with additional } \\
\text { cognitive behavior therapy } \\
\text { interventions which aim at stress } \\
\text { reduction and problem solving, self } \\
\text { monitoring, pain management, } \\
\text { change in dysfunctional cognitions, } \\
\text { reduction of avoidance behavior, } \\
\text { and wellbeing therapy for } 3 \text { weeks }\end{array}$ & $\begin{array}{c}\text { General orthopedic inpatient } \\
\text { treatment }\end{array}$ & 3 weeks & $\begin{array}{c}\text { Fear advoidance behaviours } \\
\text { (FABQ) } \\
\text { Pain (VAS) } \\
\text { Pain related disability (PDI) }\end{array}$ & $\begin{array}{l}\text { CBT can reduce back pain and increase } \\
\text { functional coping, and that this is not } \\
\text { mediated by an improvement in } \\
\text { mental health and a reduction of } \\
\text { depression, anxiety or somatization in } \\
\text { general or by induc- tion of some } \\
\text { general optimistic views. Pain is not } \\
\text { identical with mental problems. }\end{array}$ \\
\hline $\begin{array}{l}\text { Khan et al., } \\
2016\end{array}$ & $\begin{array}{l}\text { general exercise }+ \text { CBT aimed to } \\
\text { guide patients to achieve their } \\
\text { daily life goals. CBT consisted of } \\
\text { operant behavioural graded } \\
\text { activity and problem solving } \\
\text { training, for } 12 \text { weeks }\end{array}$ & $\begin{array}{c}\text { General exercise at home } 2 \text { times } \\
\text { per day and at least } 5 \text { times a } \\
\text { week (for } 12 \text { weeks) }\end{array}$ & 12 weeks & $\begin{array}{l}\text { Disability (RMDQ) } \\
\text { Pain (VAS) }\end{array}$ & $\begin{array}{l}\text { This study found that both CBT with } \\
\text { General exercises and General } \\
\text { exercises alone significantly reduced } \\
\text { pain intensity and disability in patients } \\
\text { with chronic low back pain. } \\
\text { Furthermore, subjects treated with } \\
\text { CBT \& Exercises showed an additional } \\
\text { clinical benefit as compared to General } \\
\text { Exercises only. Hence, CBT \& Exercises } \\
\text { could be a better option in clinical } \\
\text { practice. }\end{array}$ \\
\hline Pincus et al., 2015 & $\begin{array}{c}\text { Session content was not structured, } \\
\text { and at the discretion of therapists, } \\
\text { included any features of } \\
\text { Contextual Cognitive-Behavioural } \\
\text { Therapy (CCBT) they thought were } \\
\text { appropriate at the point with that } \\
\text { patient. }\end{array}$ & $\begin{array}{l}\text { Physiotherapy, comprised back } \\
\text { to fitness group exercises with at } \\
\text { least } 60 \% \text { of content } \\
\text { exercise-based. }\end{array}$ & 3 months & $\begin{array}{c}\text { Fear advoidance behaviours } \\
\text { (TSK) } \\
\text { pain (Brief Pain Inventory) } \\
\text { disability (RMDQ) } \\
\text { anxiety and depression } \\
\text { (HADS) } \\
\text { QoL (EQ-5D and SF-36) }\end{array}$ & $\begin{array}{l}\text { CCBT is a credible and acceptable } \\
\text { intervention for LBP patients who } \\
\text { exhibit psychological obstacles to } \\
\text { recovery. }\end{array}$ \\
\hline
\end{tabular}


Table 2. Cont.

\begin{tabular}{|c|c|c|c|c|c|}
\hline Study & Intervention (s) & Control & Follow-Up & Outcomes (Tool) & Conclusion \\
\hline Basler et al., 1997 & $\begin{array}{l}\text { medical treatment such as pain } \\
\text { medication, nerve blocks, TENS, } \\
\text { and physical therapy + CBT } \\
\text { therapy: education, relaxation, } \\
\text { Modifying thoughts and feelings, } \\
\text { Pleasant activity scheduling, } \\
\text { Training of posture }\end{array}$ & $\begin{array}{l}\text { Medical treatment such as pain } \\
\text { medication, nerve blocks, TENS, } \\
\text { and physical therapy }\end{array}$ & 6 months & $\begin{array}{c}\text { Pain (NRS) } \\
\text { Disability (Dusseldorf } \\
\text { disability scale) }\end{array}$ & $\begin{array}{l}\text { Experimental subjects reported less } \\
\text { pain, more pleasurable activities and } \\
\text { feelings, less avoidance and less } \\
\text { catastrophizing, and disability was } \\
\text { reduced. The results were maintained } \\
\text { at follow-up. Patients who only } \\
\text { received medical treatment showed } \\
\text { little improvement. Data indicate that } \\
\text { the program meets the needs of the } \\
\text { patients and should be continued. }\end{array}$ \\
\hline
\end{tabular}

Sessions were organized to activate with back pain by remaining

participants and promote coping. active and thinking positively.

Pain (VAS)

Each session began with a short 2. Information package: advice

Linton et al., 2007

review, in which homework was

and illustrations showing how

covered. The treatment lasts 6

the patient might cope with

12 months Depression and anxiety

$$
\text { (HAD) }
$$

Fear Advoidance (FABQ)

This study demonstrates that CBT group intervention can lower the risk of a long-term disability developing.

methods as lifting properly and

main- taining good posture.

Usual care and opioid therapy management + manualized training in the meditation-CBT intervention $2 \mathrm{~h}$ per week for 8 weeks
Pharmacotherapy, opioid therapy management and physical therapy
26 weeks
Zgierska et al., 2016

Morone et al., 2008

\section{Mindfulness: body scan, sitting} practice, walking meditation
Waiting List
Mindfulness meditation and

Pain (Brief Pain Inventory)

Disability (ODI)
CBT-based interventions have the
potential to safely reduce pain severity and sensitivity in patients with opioid-treated CLBP

Pain (McGill pain

Questionnaire- Short Form and SF-36 pain scale) Disability (RMDQ)
The mindfulness intervention sustained improvement in physical function and pain acceptance. 
Table 2. Cont.

\begin{tabular}{|c|c|c|c|c|c|}
\hline Study & Intervention (s) & Control & Follow-Up & Outcomes (Tool) & Conclusion \\
\hline Morone et al., 2009 & $\begin{array}{l}\text { Mindfulness: body scan, sitting } \\
\text { practice, walking meditation }\end{array}$ & $\begin{array}{l}\text { Educational program (8 weeks), } \\
\text { including lectures, group } \\
\text { discussion, and homework } \\
\text { assignments based on the health } \\
\text { topics discussed }\end{array}$ & 4 months & $\begin{array}{c}\text { Disability (RMDQ) } \\
\text { Pain (McGill pain } \\
\text { Questionnaire- Short Form } \\
\text { and SF-36 pain scale) } \\
\text { QoL (SF-36) }\end{array}$ & $\begin{array}{l}\text { A mindfulness meditation program } \\
\text { and an education control group both } \\
\text { showed improvement at program } \\
\text { completion on measures of pain, and } \\
\text { physical and psychological function. }\end{array}$ \\
\hline Morone et al., 2016 & $\begin{array}{c}\text { Mindfulness: body scan, sitting } \\
\text { practice, walking meditation for } 8 \\
\text { weeks }\end{array}$ & $\begin{array}{c}\text { Educational program on a } \\
\text { successful aging curriculum } \\
\text { known as the } 10 \text { Keys to Healthy } \\
\text { Aging }\end{array}$ & 6 months & $\begin{array}{l}\text { Disability (RMDQ) } \\
\text { Pain (NRS) } \\
\text { QoL (SF-36) }\end{array}$ & $\begin{array}{l}\text { A mind-body program for chronic LBP } \\
\text { improved short-term function and } \\
\text { long-term current and most severe } \\
\text { pain. The functional improvement was } \\
\text { not sustained. }\end{array}$ \\
\hline Day et al., 2019 & $\begin{array}{l}\text { MBCT for pain protocol integrates } \\
\text { cognitive and be- havioral } \\
\text { techniques with mindfulness-based } \\
\text { strategies }\end{array}$ & $\begin{array}{l}\text { CT techniques delivered: } \\
\text { treatment involved traditional } \\
\text { Beckian style column technique } \\
\text { restructuring exercises } \\
\text { Mindufulness: } \\
\text { cognitive-behavioral and mindful } \\
\text { movement components removed }\end{array}$ & 6 months & $\begin{array}{c}\text { Pain (NRS) } \\
\text { Physical function (PROMIS) } \\
\text { Depression (PROMIS) }\end{array}$ & $\begin{array}{l}\text { The findings show that MBCT is a } \\
\text { feasible, tolerable, acceptable, and } \\
\text { potentially efficacious treatment option } \\
\text { for CLBP. Further, MBCT, and possibly } \\
\text { CT, could have sus- tained benefits } \\
\text { that exceed MM on some important } \\
\text { CLBP outcomes. }\end{array}$ \\
\hline
\end{tabular}


Table 3. Cochrane risk-of-bias tool for randomized controlled trials.

\begin{tabular}{|c|c|c|c|c|c|c|c|c|}
\hline & $\begin{array}{l}\text { Random } \\
\text { Sequence } \\
\text { Genera- } \\
\text { tion }\end{array}$ & $\begin{array}{c}\text { Allocation } \\
\text { Conceal- } \\
\text { ment }\end{array}$ & $\begin{array}{c}\text { Blinding } \\
\text { (Participants } \\
\text { and } \\
\text { Personnel) }\end{array}$ & $\begin{array}{l}\text { Blinding } \\
\text { (Outcome } \\
\text { Assess- } \\
\text { ment) }\end{array}$ & $\begin{array}{c}\text { Incomplete } \\
\text { Outcome } \\
\text { Data }\end{array}$ & $\begin{array}{l}\text { Selective } \\
\text { Reporting }\end{array}$ & $\begin{array}{l}\text { Other } \\
\text { Bias }\end{array}$ & $\begin{array}{c}\text { Risk of } \\
\text { Bias }\end{array}$ \\
\hline $\begin{array}{c}\text { Cherkin et al., } \\
2016\end{array}$ & L & $\mathrm{L}$ & $\mathrm{H}$ & $\mathrm{L}$ & $\mathrm{L}$ & $\mathrm{L}$ & $\mathrm{H}$ & $\mathrm{U}$ \\
\hline $\begin{array}{l}\text { Monticone } \\
\text { et al., } 2013\end{array}$ & $\mathrm{~L}$ & $\mathrm{~L}$ & $\mathrm{H}$ & $\mathrm{L}$ & $\mathrm{L}$ & $\mathrm{L}$ & $\mathrm{L}$ & $\mathrm{L}$ \\
\hline $\begin{array}{c}\text { Johnson et al., } \\
2007\end{array}$ & L & $\mathrm{L}$ & $\mathrm{H}$ & $\mathrm{H}$ & $\mathrm{L}$ & $\mathrm{L}$ & $\mathrm{H}$ & $\mathrm{U}$ \\
\hline $\begin{array}{l}\text { Smeets et al., } \\
2006\end{array}$ & L & $\mathrm{L}$ & $\mathrm{H}$ & $\mathrm{L}$ & $\mathrm{L}$ & $\mathrm{L}$ & $\mathrm{H}$ & $\mathrm{U}$ \\
\hline $\begin{array}{l}\text { Rutledge et al., } \\
\qquad 2018\end{array}$ & $\mathrm{~L}$ & $\mathrm{~L}$ & $\mathrm{H}$ & $\mathrm{L}$ & $\mathrm{L}$ & $\mathrm{L}$ & $\mathrm{H}$ & $\mathrm{U}$ \\
\hline $\begin{array}{l}\text { Rutledge T } \\
\text { et al., } 2018\end{array}$ & $\mathrm{~L}$ & $\mathrm{~L}$ & $\mathrm{H}$ & $\mathrm{H}$ & $\mathrm{L}$ & $\mathrm{L}$ & $\mathrm{L}$ & $\mathrm{U}$ \\
\hline $\begin{array}{l}\text { Linden et al., } \\
2014\end{array}$ & $\mathrm{~L}$ & $\mathrm{U}$ & $\mathrm{H}$ & $\mathrm{L}$ & $\mathrm{L}$ & $\mathrm{L}$ & $\mathrm{H}$ & $\mathrm{U}$ \\
\hline $\begin{array}{l}\text { Khan et al., } \\
\quad 2016\end{array}$ & $\mathrm{~L}$ & $\mathrm{U}$ & $\mathrm{H}$ & $\mathrm{L}$ & $\mathrm{L}$ & $\mathrm{L}$ & $\mathrm{H}$ & $\mathrm{U}$ \\
\hline $\begin{array}{c}\text { Pincus et al., } \\
2015\end{array}$ & $\mathrm{~L}$ & $\mathrm{~L}$ & $\mathrm{H}$ & $\mathrm{U}$ & $\mathrm{L}$ & $\mathrm{L}$ & $\mathrm{H}$ & $\mathrm{U}$ \\
\hline $\begin{array}{c}\text { Basler et al., } \\
1997\end{array}$ & $\mathrm{~L}$ & $\mathrm{~L}$ & $\mathrm{H}$ & $\mathrm{L}$ & $\mathrm{L}$ & $\mathrm{L}$ & $\mathrm{H}$ & $\mathrm{U}$ \\
\hline $\begin{array}{l}\text { Linton et al., } \\
2000\end{array}$ & $\mathrm{~L}$ & $\mathrm{U}$ & $\mathrm{H}$ & $\mathrm{U}$ & $\mathrm{L}$ & $\mathrm{L}$ & $\mathrm{H}$ & $\mathrm{H}$ \\
\hline $\begin{array}{l}\text { Zgierska et al., } \\
2016\end{array}$ & $\mathrm{~L}$ & $\mathrm{U}$ & $\mathrm{H}$ & $\mathrm{H}$ & $\mathrm{L}$ & $\mathrm{L}$ & $\mathrm{H}$ & $\mathrm{H}$ \\
\hline $\begin{array}{l}\text { Morone et al., } \\
2008\end{array}$ & $\mathrm{~L}$ & $\mathrm{U}$ & $\mathrm{U}$ & $\mathrm{H}$ & $\mathrm{L}$ & $\mathrm{L}$ & $\mathrm{H}$ & $\mathrm{H}$ \\
\hline $\begin{array}{l}\text { Morone et al., } \\
2009\end{array}$ & $\mathrm{~L}$ & $\mathrm{~L}$ & $\mathrm{U}$ & $\mathrm{L}$ & $\mathrm{H}$ & $\mathrm{L}$ & $\mathrm{L}$ & $\mathrm{L}$ \\
\hline $\begin{array}{l}\text { Morone et al., } \\
2016\end{array}$ & $\mathrm{~L}$ & $\mathrm{~L}$ & $\mathrm{U}$ & $\mathrm{L}$ & $\mathrm{L}$ & $\mathrm{U}$ & $\mathrm{L}$ & $\mathrm{L}$ \\
\hline Day et al., 2019 & $\mathrm{~L}$ & $\mathrm{~L}$ & $\mathrm{H}$ & $\mathrm{L}$ & $\mathrm{L}$ & $\mathrm{L}$ & $\mathrm{L}$ & $\mathrm{L}$ \\
\hline
\end{tabular}

L: low; U: unclear; H: high.

\subsection{Effect of Intervention}

The meta-analysis analyzed the effectiveness of CBT and MBSR in terms of pain, disability, quality of life, depression and Fear-Avoidance Beliefs compared to controls.

\subsubsection{Pain}

Pain showed a significant decrease both in CBT and MBSR group compared with the control group, respectively SMD $-0.73,95 \% \mathrm{CI}-1.20$ to $-0.26, p=0.002$ for CBT (Figure 2) and SMD $-0.30,95 \% \mathrm{CI}-0.47$ to $-0.13, p=0.0005$ for MBSR (Figure 3). No significant pain reduction was demonstrated ( $\mathrm{MD}-0.05,95 \% \mathrm{CI}-0.50$ to $0.39, p=0.81$ ) when comparing MBSR and CBT (Figure 4). 


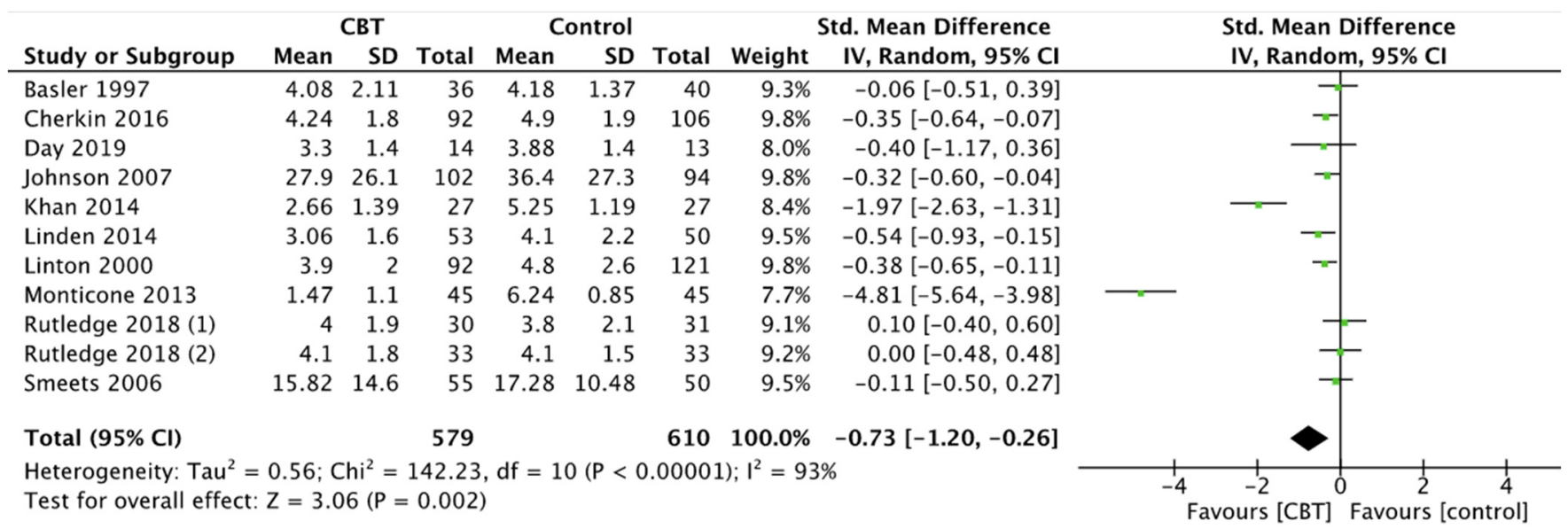

Figure 2. Pain: CBT versus control.

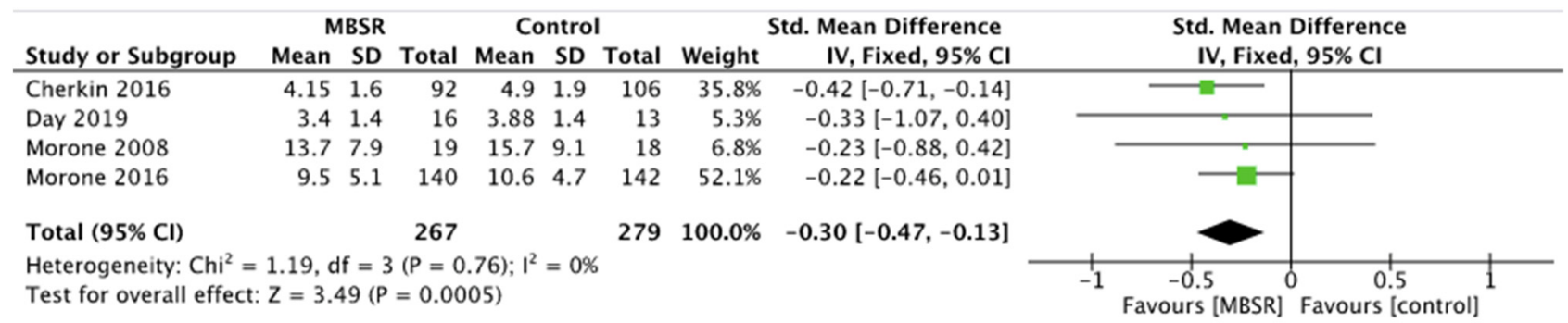

Figure 3. Pain: MBSR versus control.

\begin{tabular}{|c|c|c|c|c|c|c|c|c|c|}
\hline \multirow[b]{2}{*}{ Study or Subgroup } & \multicolumn{3}{|c|}{ MBSR } & \multicolumn{3}{|c|}{ CBT } & \multicolumn{2}{|r|}{ Mean Difference } & \multirow{2}{*}{$\begin{array}{l}\text { Mean Difference } \\
\text { IV, Fixed, } 95 \% \mathrm{Cl}\end{array}$} \\
\hline & Mean & SD & Total & Mean & SD & Total & Weight & IV, Fixed, 95\% CI & \\
\hline Cherkin 2016 & 4.15 & 1.6 & 92 & 4.24 & 1.8 & 92 & $80.6 \%$ & $-0.09[-0.58,0.40]$ & \\
\hline Day 2019 & 3.4 & 1.4 & 16 & 3.3 & 1.4 & 14 & $19.4 \%$ & $0.10[-0.90,1.10]$ & \\
\hline Total $(95 \% \mathrm{CI})$ & & & 108 & & & 106 & $100.0 \%$ & $-0.05[-0.50,0.39]$ & \\
\hline \multicolumn{9}{|c|}{$\begin{array}{l}\text { Heterogeneity: } \mathrm{Chi}^{2}=0.11, \mathrm{df}=1(P=0.74) ; \mathrm{I}^{2}=0 \% \\
\text { Test for overall effect: } Z=0.24(P=0.81)\end{array}$} & $\begin{array}{ccccc}-1 & -0.5 & 0 & 0.5 & 1 \\
\text { Favours } & {[\mathrm{MBSR}]} & \text { Favours } & \text { [CBT] }\end{array}$ \\
\hline
\end{tabular}

Figure 4. Pain: MBSR versus CBT.

\subsubsection{Disability}

Disability scores demonstrated significant improvements after CBT in comparison with controls (SMD $-0.88,95 \%$ CI -1.50 to $-0.26, p=0.005$ ) (Figure 5). Instead, the reduction of disability after MBSR was not statistically significant compared to controls (MD $-0.71,95 \% \mathrm{CI}-1.53$ to $-0.11, p=0.09$ ) (Figure 6).

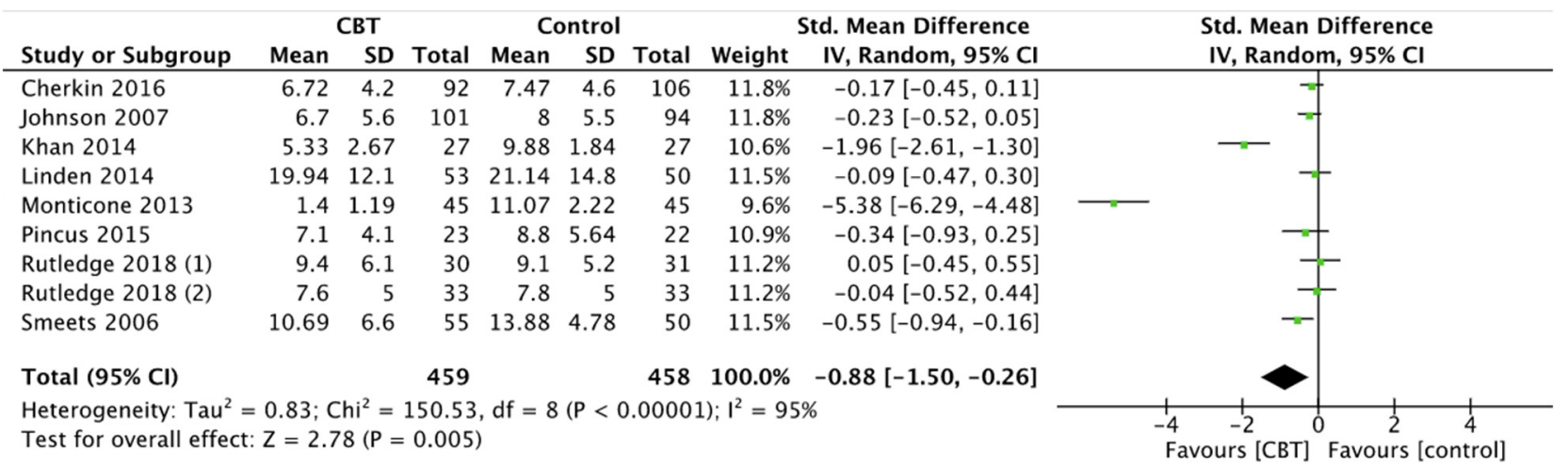

Figure 5. Disability: CBT versus control. 


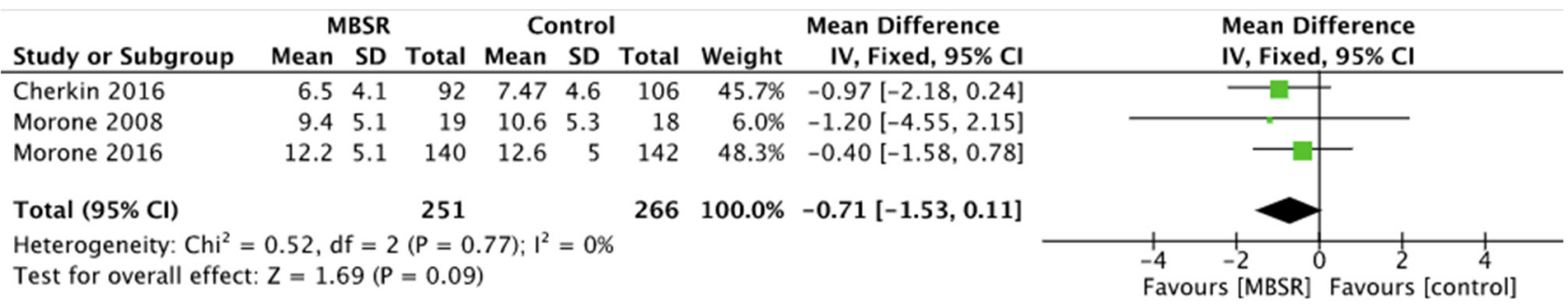

Figure 6. Disability: MBSR versus control.

\subsubsection{Quality of Life}

Quality of life showed significant improvement in CBT and MBSR group compared to controls, respectively SMD $0.69,95 \%$ CI 0.00 to $1.37, p=0.05$ for CBT (Figure 7) and MD 2.84, 95\% CI 0.31 to 5.37, $p=0.03$ for MBSR (Figure 8). Moreover, comparing the two intervention groups, a significant difference in quality of life was shown in favor of MBSR (MD 2.54, 95\% CI 0.84 to $4.24, p=0.003$ ) (Figure 9).

\begin{tabular}{|c|c|c|c|c|c|c|c|c|c|}
\hline \multirow[b]{2}{*}{ Study or Subgroup } & \multicolumn{3}{|c|}{ CBT } & \multicolumn{3}{|c|}{ Control } & \multicolumn{2}{|r|}{ Std. Mean Difference } & \multirow{2}{*}{$\begin{array}{l}\text { Std. Mean Difference } \\
\text { IV, Random, } 95 \% \mathrm{CI}\end{array}$} \\
\hline & Mean & SD & Total & Mean & SD & Total & Weight & IV, Random, $95 \% \mathrm{Cl}$ & \\
\hline Cherkin 2016 & 42.2 & 6.4 & 92 & 41.6 & 7.2 & 106 & $27.3 \%$ & $0.09[-0.19,0.37]$ & $-1=$ \\
\hline Day 2019 & 43.79 & 5.4 & 14 & 38.17 & 5.4 & 13 & $20.4 \%$ & $1.01[0.20,1.82]$ & \\
\hline Johnson 2007 & 0.75 & 0.23 & 89 & 0.71 & 0.23 & 81 & $27.1 \%$ & $0.17[-0.13,0.47]$ & $f=$ \\
\hline Monticone 2013 & 86.33 & 13.24 & 45 & 63.11 & 15.01 & 45 & $25.1 \%$ & $1.63[1.15,2.11]$ & \\
\hline \multicolumn{3}{|l|}{ Total $(95 \% \mathrm{Cl})$} & 240 & & & 245 & $100.0 \%$ & $0.69[0.00,1.37]$ & \\
\hline \multicolumn{9}{|c|}{$\begin{array}{l}\text { Heterogeneity: } \mathrm{Tau}^{2}=0.42 ; \mathrm{Chi}^{2}=34.31, \mathrm{df}=3(\mathrm{P}<0.00001) ; \mathrm{I}^{2}=91 \% \\
\text { Test for overall effect: } Z=1.97(P=0.05)\end{array}$} & $-2 \quad \begin{array}{ll}-1 & 0 \\
& \text { Favours [control] Favou }\end{array}$ \\
\hline
\end{tabular}

Figure 7. Quality of Life: CBT versus control.

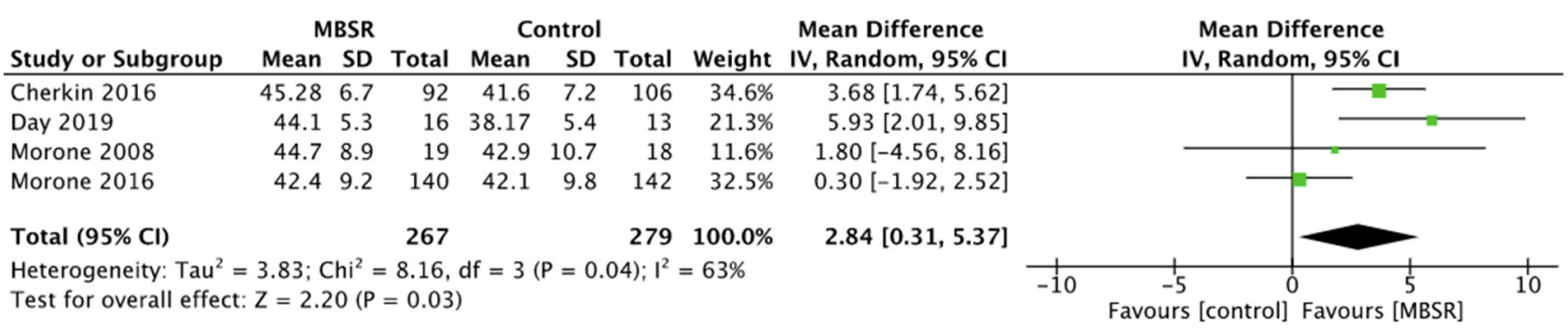

Figure 8. Quality of Life: MBSR versus control.

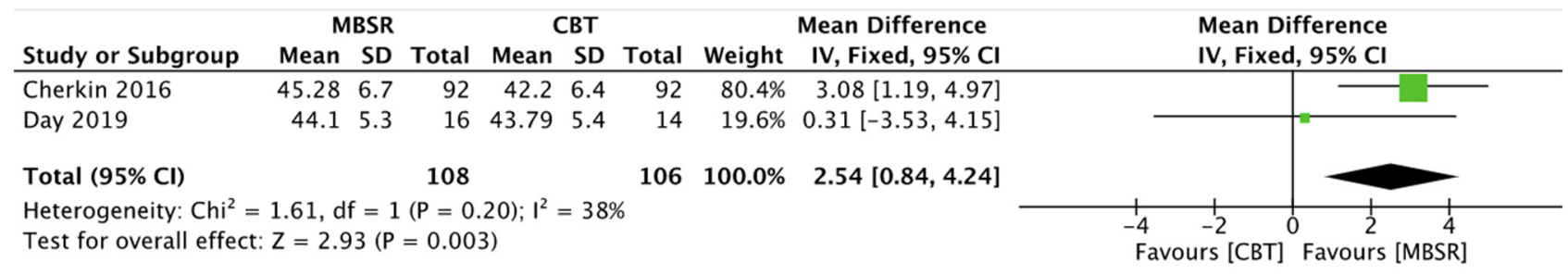

Figure 9. Quality of Life: MBSR versus CBT.

\subsubsection{Depression}

Depression scales did not show significant differences between the groups. More precisely, depression did not report statistical improvements between CBT and controls (SMD $-0.26,95 \% \mathrm{CI}-0.72$ to $0.19, p=0.26$ ) (Figure 10), MBRS and controls (SMD -1.55 , $95 \% \mathrm{CI}-4.53$ to $1.43, p=0.31$ ) (Figure 11 ), and also MBRS and CBT (SMD 0.00, 95\% CI -0.27 to $0.27, p=1.00$ ) (Figure 12). 


\begin{tabular}{|c|c|c|c|c|c|c|c|c|c|}
\hline \multirow[b]{2}{*}{ Study or Subgroup } & \multicolumn{3}{|c|}{ CBT } & \multicolumn{3}{|c|}{ Control } & \multicolumn{2}{|r|}{ Std. Mean Difference } & \multirow{2}{*}{$\begin{array}{l}\text { Std. Mean Difference } \\
\text { IV, Random, } 95 \% \mathrm{CI}\end{array}$} \\
\hline & Mean & SD & Total & Mean & SD & Total & Weight & IV, Random, 95\% Cl & \\
\hline Cherkin 2016 & 3.98 & 2.6 & 92 & 4.42 & 2.9 & 106 & $23.7 \%$ & $-0.16[-0.44,0.12]$ & \\
\hline Day 2019 & 46.14 & 4.1 & 14 & 57.54 & 4.3 & 13 & $10.7 \%$ & $-2.63[-3.71,-1.56]$ & \\
\hline Linton 2000 & 3.9 & 3.5 & 92 & 3.95 & 3 & 121 & $23.9 \%$ & $-0.02[-0.29,0.26]$ & 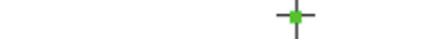 \\
\hline Rutledge 2018 (1) & 15 & 13.6 & 30 & 10.3 & 9.9 & 31 & $19.7 \%$ & $0.39[-0.12,0.90]$ & \\
\hline Smeets 2006 & 8.8 & 6.7 & 55 & 9.42 & 7.81 & 50 & $22.0 \%$ & $-0.08[-0.47,0.30]$ & \\
\hline Total $(95 \% \mathrm{Cl})$ & & & 283 & & & 321 & $100.0 \%$ & $-0.26[-0.72,0.19]$ & \\
\hline \multicolumn{9}{|c|}{$\begin{array}{l}\text { Heterogeneity: } \operatorname{Tau}^{2}=0.21 ; \mathrm{Chi}^{2}=25.64, \mathrm{df}=4(\mathrm{P}<0.0001) ; \mathrm{I}^{2}=84 \% \\
\text { Test for overall effect: } Z=1.14(P=0.26)\end{array}$} & $\begin{array}{cc}-2 & 0 \\
\text { Favours [CBT] Favours [ }\end{array}$ \\
\hline
\end{tabular}

Figure 10. Depression: CBT versus control.

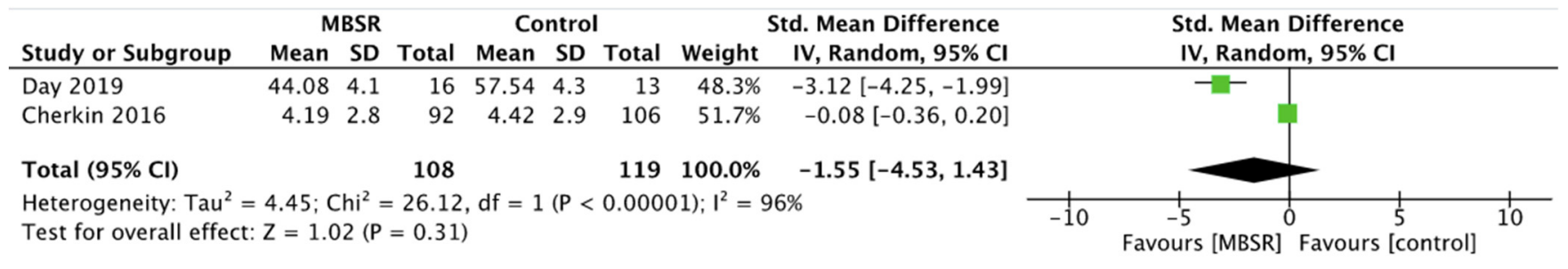

Figure 11. Depression: MBSR versus control.

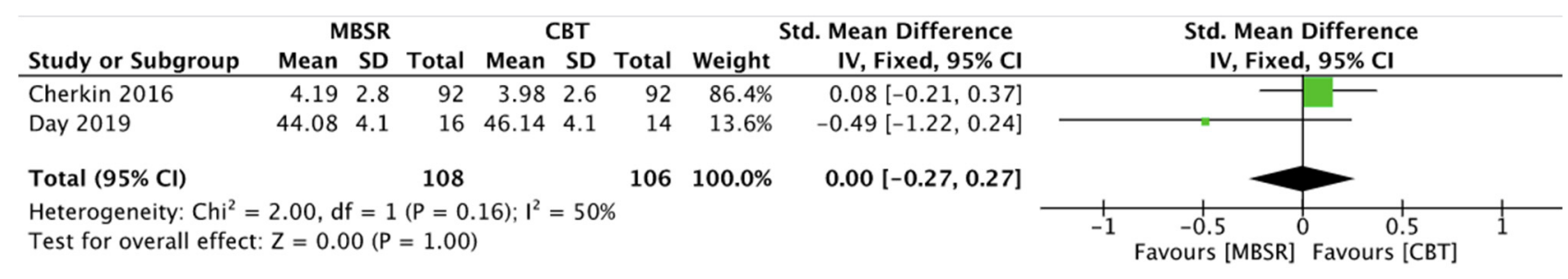

Figure 12. Depression: MBSR versus CBT.

\subsubsection{Fear-Avoidance Beliefs}

The meta-analysis demonstrated lower fear-avoidance beliefs in patients who underwent CBT compared to control group (SMD $-2.17,95 \% \mathrm{CI}-4.22$ to $-012, p=0.04$ ) (Figure 13).

\begin{tabular}{|c|c|c|c|c|c|c|c|c|c|}
\hline \multirow[b]{2}{*}{ Study or Subgroup } & \multicolumn{3}{|c|}{ CBT } & \multicolumn{3}{|c|}{ Control } & \multicolumn{2}{|r|}{ Std. Mean Difference } & \multirow{2}{*}{$\begin{array}{l}\text { Std. Mean Difference } \\
\text { IV, Random, } 95 \% \mathrm{Cl}\end{array}$} \\
\hline & Mean & SD & Total & Mean & SD & Total & Weight & IV, Random, 95\% Cl & \\
\hline Linden 2014 & 34.28 & 17.9 & 53 & 46.1 & 20.3 & 50 & $34.0 \%$ & $-0.61[-1.01,-0.22]$ & $-\frac{-1}{2-1}$ \\
\hline Linton 2000 & 8 & 4.7 & 92 & 8.7 & 5.8 & 121 & $34.2 \%$ & $-0.13[-0.40,0.14]$ & 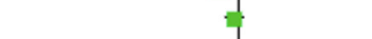 \\
\hline Monticone 2013 & 17.67 & 1.62 & 45 & 40.96 & 5.17 & 45 & $31.8 \%$ & $-6.03[-7.02,-5.04]$ & $-=$ \\
\hline Total $(95 \% \mathrm{Cl})$ & & & 190 & & & 216 & $100.0 \%$ & $-2.17[-4.22,-0.12]$ & \\
\hline \multicolumn{10}{|c|}{$\begin{array}{l}\text { Heterogeneity: } \mathrm{Tau}^{2}=3.18 ; \mathrm{Chi}^{2}=126.69, \mathrm{df}=2(\mathrm{P}<0.00001) ; \mathrm{I}^{2}=98 \% \\
\text { Test for overall effect: } \mathrm{Z}=2.08(\mathrm{P}=0.04)\end{array}$} \\
\hline
\end{tabular}

Figure 13. Fear-Avoidance beliefs: CBT versus control.

3.6.6. Days without Pain

Finally, the number of days without LBP increased in CBT group compared to controls, but without statistical significance (OR 1.38, 95\% CI 0.73 to $2.61, p=0.32$ ) (Figure 14). 


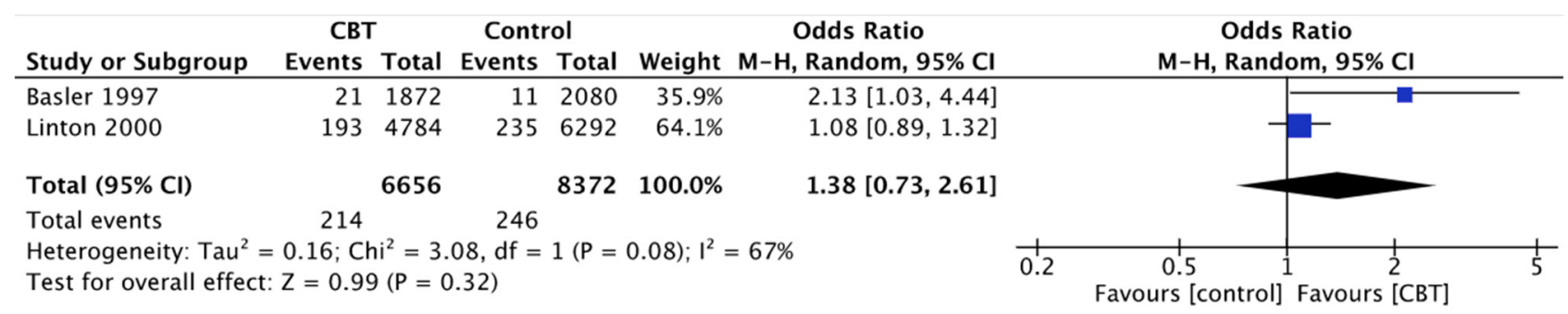

Figure 14. Days without pain: CBT versus control.

\section{Discussion}

The link between psychological factors and CLBP has been widely demonstrated in several studies. The aims of this Systematic Review and Meta-Analysis were (1) to identify and describe the most frequently used psychological approaches to treat patients affected by CLBP, and (2) to study the effectiveness of these approaches in terms of reduction of pain, disability, fear-avoidance behaviors, anxiety, depression, and of increase in quality of life. According to the literature $[16,19,21]$, the most common psychological approaches used to treat CLBP are cognitive behavioral therapy and mindfulness-based intervention. CBT demonstrated its effectiveness for different chronic pain conditions [7]. This approach helps patients with maladaptive emotions, behaviors, and cognitions through a goal-oriented and systematic process. CBT was initially used to treat disorders like insomnia, anxiety, and depression, and was later implemented to manage chronic pain [39]. The CBT intervention consists in several sessions guided by a skilled therapist, with different frequency and duration. In these sessions, activities like pain education, relaxation training, managing of automatic thoughts, stress reduction, problem solving and sleep education [39] are performed. MBSR is also becoming increasingly popular and available in the United States [9]. With this treatment, patients are educated about the psychophysiology of stress and are provided opportunities to apply MBSR skills to specific situations [40]. This approach has several contemporary interpretations, based on formal and informal systematic meditation training, patient education, yoga exercises, and individual and group dialogue [41].

The findings of this systematic review and meta-analysis suggest that CBT and MBSR interventions were both associated with an improvement in terms of pain intensity and quality of life when singularly compared to usual care. Disability also improved in both groups when compared to usual care, although it was only statistically significant in patients treated with CBT, which may be due to the paucity of studies that analyzed MBSR intervention. Significant differences in fear-avoidance beliefs were noted in the CBT group compared to usual care. However, no studies analyzed this outcome for the MBSR approach. No meaningful results were noted for depression in both MBSR and CBT groups. Moreover, only two RCT compared CBT to MBSR, showing no significant improvements in pain intensity and depression along with a better quality of life for the MBSR intervention $[9,28]$.

Another meta-analysis [20] studied several psychosocial interventions to treat patients affected by CLBP. This study demonstrated an improvement in pain, QoL and work-related disability in the intervention group towards the waiting list group.

Our results agree with those by Gotink et al. [22], who studied MBSR applied to chronic illness. Their review shows the large use of this treatment with patients affected by cancer, cardiovascular diseases, mental disorders, and non-specific chronic pain. Indeed, an improvement in depressive symptoms and physical health and a decrease in pain burden, intensity and disability are reported in patients affected by non-specific chronic pain.

Regarding the implementation of CBT, Richmond et al. [19] shows its effectiveness for non-specific low back pain, with improvement of pain, functional disability, and quality of life. In addition, Morley et al. [42] show the improvement of pain and functional disability in patients with chronic pain. 
Psychological factors in people affected by LBP are associated with increased risk of developing disability [43]. For instance, the symptom of depression and the catastrophizing of pain predict poor low back pain-related outcomes [44,45]. Therefore, cognitive and emotional factors have a crucial impact on pain perception and, in line with the literature [46], it is fundamental to identify and take care of psychological factors, through a multidisciplinary approach in patients with chronic pain. Indeed this approach should be considered because each aspect requires specific interventions [47].

This review has several limitations. Firstly, there is some difference in heterogeneity between studies regarding CBT and MBSR. In particular, the studies involving CBT presented high heterogeneity due to the greater number of studies included, the different types of CBT performed, the different duration of interventions, and the tools used. Instead, the studies investigating MBSR used the same tools for the analyzed outcomes, resulting therefore in lower heterogeneity. Additionally, demographic characteristics of the participants were different in the included studies, with various gender and age distribution. However, this did not influence the statistical analysis of the studies. There are differences regarding the quality of the studies; indeed, the major number of the studies included were of moderate quality $(n=9)$, whereas four studies had a low risk of bias, and three studies had a high risk of bias. We also decided to include in the meta-analysis the studies with a high risk of bias, which is another limitation regarding the number of studies included. The participants of most studies, except for three studies [25-27], were not blind to treatment allocation, given the nature of the intervention. Another limitation of this study is the heterogeneity of the types of treatment in the control groups. Indeed, we found different types of treatments in the control groups such as physiotherapy, physical exercises, educational programs and drug treatments. In only two studies we found the waiting list, and we suppose it may be the most adequate control group for the reduction of bias, hence the need to develop RCTs with waiting lists as a control group for an appropriate analysis of the effectiveness of psychological interventions. To reduce the heterogeneity in the analysis of outcomes as pain, it would be appropriate to develop RCTs that use the same tools.

\section{Conclusions}

In the present study we analyzed the most used and effective psychological approaches to treat patients affected by chronic LBP. CBT and MBSR have proven their significant effectiveness to improve pain intensity and quality of life compared to controls. These approaches also demonstrated their efficacy in reducing disability and fear-avoidance, but without significant results. The importance of treating psychological aspects is widely proven, but the paucity and heterogeneity of the studies included cannot make us confident to affirm which is the most effective treatment. Further studies are needed to compare CBT and MBSR.

Author Contributions: Conceptualization, G.P., G.F.P., F.R. and G.V.; methodology, G.P., G.F.P., F.R. and G.V.; formal analysis, G.P., G.F.P. and F.R.; data curation, G.P., G.F.P. and F.R.; writing-original draft preparation, G.P., G.F.P., F.R., G.V., M.P. and M.G.D.M.; writing-review and editing, G.P., G.F.P., F.R., G.V., M.P., M.G.D.M., R.P. and V.D.; supervision, F.R., G.V., M.P., M.G.D.M., R.P. and V.D. All authors have read and agreed to the published version of the manuscript.

Funding: This research was funded by the Research Grant (BRiC-2018 ID3) of the Italian Workers' Compensation Authority (INAIL).

Institutional Review Board Statement: Not applicable.

Informed Consent Statement: Not applicable.

Acknowledgments: Not applicable.

Conflicts of Interest: The authors declare no conflict of interest. 


\section{References}

1. Vos, T.; Barber, R.M.; Bell, B.; Bertozzi-Villa, A.; Biryukov, S.; Bolliger, I.; Charlson, F.; Davis, A.; Degenhardt, L.; Dicker, D.; et al. Global, regional, and national incidence, prevalence, and years lived with disability for 301 acute and chronic diseases and injuries in 188 countries, 1990-2013: A systematic analysis for the Global Burden of Disease Study 2013. Lancet 2015, 386, 743-800. [CrossRef]

2. Russo, F.; Papalia, G.F.; Vadalà, G.; Fontana, L.; Iavicoli, S.; Papalia, R.; Denaro, V. The Effects of Workplace Interventions on Low Back Pain in Workers: A Systematic Review and Meta-Analysis. Int. J. Environ. Res. Public. Health 2021, 18, 12614. [CrossRef] [PubMed]

3. Andersson, G.B. Epidemiological features of chronic low-back pain. Lancet 1999, 354, 581-585. [CrossRef]

4. Deyo, R.A.; Mirza, S.K.; Martin, B.I. Back Pain Prevalence and Visit Rates: Estimates from U.S. National Surveys, 2002. Spine 2006, 31, 2724-2727. [CrossRef] [PubMed]

5. Rubin, D.I. Epidemiology and Risk Factors for Spine Pain. Neurol. Clin. 2007, 25, 353-371. [CrossRef] [PubMed]

6. Neugebauer, V.; Galhardo, V.; Maione, S.; Mackey, S. Forebrain pain mechanisms. Brain Res. Rev. 2009, 60, 226-242. [CrossRef]

7. Williams, A.C.D.C.; Fisher, E.; Hearn, L.; Eccleston, C. Psychological therapies for the management of chronic pain (excluding headache) in adults. Cochrane Database Syst. Rev. 2020, 2021. [CrossRef]

8. Russo, F.; Ambrosio, L.; Ngo, K.; Vadalà, G.; Denaro, V.; Fan, Y.; Sowa, G.; Kang, J.D.; Vo, N. The Role of Type I Diabetes in Intervertebral Disc Degeneration. Spine 2019, 44, 1177-1185. [CrossRef]

9. Cherkin, D.C.; Sherman, K.J.; Balderson, B.H.; Cook, A.J.; Anderson, M.L.; Hawkes, R.J.; Hansen, K.E.; Turner, J.A. Effect of Mindfulness-Based Stress Reduction vs. Cognitive Behavioral Therapy or Usual Care on Back Pain and Functional Limitations in Adults With Chronic Low Back Pain: A Randomized Clinical Trial. JAMA 2016, 315, 1240. [CrossRef]

10. Russo, F.; De Salvatore, S.; Ambrosio, L.; Vadalà, G.; Fontana, L.; Papalia, R.; Rantanen, J.; Iavicoli, S.; Denaro, V. Does Workers Compensation Status Affect Outcomes after Lumbar Spine Surgery? A Systematic Review and Meta-Analysis. Int. J. Environ. Res. Public Health 2021, 18, 6165. [CrossRef]

11. Gatchel, R.J.; Peng, Y.B.; Peters, M.; Fuchs, P.; Turk, D.C. The biopsychosocial approach to chronic pain: Scientific advances and future directions. Psychol. Bull. 2007, 133, 581-624. [CrossRef]

12. Keefe, F.J.; Rumble, M.E.; Scipio, C.D.; Giordano, L.A.; Perri, L.M. Psychological aspects of persistent pain: Current state of the science. J. Pain 2004, 5, 195-211. [CrossRef] [PubMed]

13. Smeets, R.J.; Vlaeyen, J.; Kester, A.D.; Knottnerus, J.A. Reduction of Pain Catastrophizing Mediates the Outcome of Both Physical and Cognitive-Behavioral Treatment in Chronic Low Back Pain. J. Pain 2006, 7, 261-271. [CrossRef]

14. Sullivan, M.J.L.; Thorn, B.; Haythornthwaite, J.A.; Keefe, F.; Martin, M.; Bradley, L.; Lefebvre, J.C. Theoretical Perspectives on the Relation Between Catastrophizing and Pain. Clin. J. Pain 2001, 17, 52-64. [CrossRef] [PubMed]

15. Jarvik, J.G.; Hollingworth, W.; Heagerty, P.J.; Haynor, D.R.; Boyko, E.J.; Deyo, R.A. Three-Year Incidence of Low Back Pain in an Initially Asymptomatic Cohort: Clinical and Imaging Risk Factors. Spine 2005, 30, 1541-1548. [CrossRef] [PubMed]

16. Hajihasani, A.; Rouhani, M.; Salavati, M.; Hedayati, R.; Kahlaee, A.H. The Influence of Cognitive Behavioral Therapy on Pain, Quality of Life, and Depression in Patients Receiving Physical Therapy for Chronic Low Back Pain: A Systematic Review. PMER 2019, 11, 167-176. [CrossRef]

17. Vadalà, G.; Russo, F.; De Salvatore, S.; Cortina, G.; Albo, E.; Papalia, R.; Denaro, V. Physical Activity for the Treatment of Chronic Low Back Pain in Elderly Patients: A Systematic Review. J. Clin. Med. 2020, 9, 1023. [CrossRef]

18. Chou, R.; Loeser, J.D.; Owens, D.K.; Rosenquist, R.W.; Atlas, S.J.; Baisden, J.; Carragee, E.J.; Grabois, M.; Murphy, D.R.; Resnick, D.K.; et al. Interventional Therapies, Surgery, and Interdisciplinary Rehabilitation for Low Back Pain: An Evidence-Based Clinical Practice Guideline from the American Pain Society. Spine 2009, 34, 1066-1077. [CrossRef]

19. Richmond, H.; Hall, A.M.; Copsey, B.; Hansen, Z.; Williamson, E.; Hoxey-Thomas, N.; Cooper, Z.; Lamb, S.E. The Effectiveness of Cognitive Behavioural Treatment for Non-Specific Low Back Pain: A Systematic Review and Meta-Analysis. PLoS ONE 2015, 10, e0134192. [CrossRef] [PubMed]

20. Hoffman, B.M.; Papas, R.K.; Chatkoff, D.K.; Kerns, R.D. Meta-analysis of psychological interventions for chronic low back pain. Health Psychol. 2007, 26, 1-9. [CrossRef]

21. Anheyer, D.; Haller, H.; Barth, J.; Lauche, R.; Dobos, G.; Cramer, H. Mindfulness-Based Stress Reduction for Treating Low Back Pain: A Systematic Review and Meta-Analysis. Ann. Intern. Med. 2017, 166, 799. [CrossRef]

22. Gotink, R.A.; Chu, P.; Busschbach, J.J.V.; Benson, H.; Fricchione, G.L.; Hunink, M.G.M. Standardised Mindfulness-Based Interventions in Healthcare: An Overview of Systematic Reviews and Meta-Analyses of RCTs. PLoS ONE 2015, 10, e0124344. [CrossRef]

23. Page, M.J.; Moher, D. Evaluations of the uptake and impact of the Preferred Reporting Items for Systematic reviews and Meta-Analyses (PRISMA) Statement and extensions: A scoping review. Syst. Rev. 2017, 6, 263. [CrossRef] [PubMed]

24. Higgins, J.P.T.; Altman, D.G.; Gøtzsche, P.C.; Jüni, P.; Moher, D.; Oxman, A.D.; Savović, J.; Schulz, K.F.; Weeks, L.; Sterne, J.; et al The Cochrane Collaboration's tool for assessing risk of bias in randomised trials. BMJ 2011, 343, d5928. [CrossRef] [PubMed]

25. Morone, N.E.; Greco, C.M.; Weiner, D.K. Mindfulness meditation for the treatment of chronic low back pain in older adults: A randomized controlled pilot study. Pain 2008, 134, 310-319. [CrossRef] [PubMed]

26. Morone, N.E.; Rollman, B.L.; Moore, C.G.; Li, Q.; Weiner, D.K. A Mind-Body Program for Older Adults with Chronic Low Back Pain: Results of a Pilot Study. Pain Med. 2009, 10, 1395-1407. [CrossRef] 
27. Morone, N.E.; Greco, C.M.; Moore, C.G.; Rollman, B.L.; Lane, B.; Morrow, L.A.; Glynn, N.W.; Weiner, D.K. A Mind-Body Program for Older Adults with Chronic Low Back Pain: A Randomized Clinical Trial. JAMA Intern. Med. 2016, 176, 329. [CrossRef]

28. Day, M.A.; Ward, L.C.; Ehde, D.M.; Thorn, B.E.; Burns, J.; Barnier, A.; Mattingley, J.B.; Jensen, M.P. A Pilot Randomized Controlled Trial Comparing Mindfulness Meditation, Cognitive Therapy, and Mindfulness-Based Cognitive Therapy for Chronic Low Back Pain. Pain Med. 2019, 20, 2134-2148. [CrossRef]

29. Monticone, M.; Ferrante, S.; Rocca, B.; Baiardi, P.; Farra, F.D.; Foti, C. Effect of a Long-Lasting Multidisciplinary Program on Disability and Fear-Avoidance Behaviors in Patients With Chronic Low Back Pain: Results of a Randomized Controlled Trial. Clin. J. Pain 2013, 29, 929-938. [CrossRef]

30. Rutledge, T.; Atkinson, J.H.; Chircop-Rollick, T.; D'Andrea, J.; Garfin, S.; Patel, S.; Penzien, D.B.; Wallace, M.; Weickgenant, A.L.; Slater, M. Randomized Controlled Trial of Telephone-delivered Cognitive Behavioral Therapy Versus Supportive Care for Chronic Back Pain. Clin. J. Pain 2018, 34, 322-327. [CrossRef]

31. Rutledge, T.; Atkinson, J.H.; Holloway, R.; Chircop-Rollick, T.; D'Andrea, J.; Garfin, S.R.; Patel, S.; Penzien, D.B.; Wallace, M.; Weickgenant, A.L.; et al. Randomized Controlled Trial of Nurse-Delivered Cognitive-Behavioral Therapy Versus Supportive Psychotherapy Telehealth Interventions for Chronic Back Pain. J. Pain 2018, 19, 1033-1039. [CrossRef] [PubMed]

32. Johnson, R.E.; Jones, G.T.; Wiles, N.J.; Chaddock, C.; Potter, R.G.; Roberts, C.; Symmons, D.P.M.; Watson, P.J.; Torgerson, D.J.; Macfarlane, G.J. Active Exercise, Education, and Cognitive Behavioral Therapy for Persistent Disabling Low Back Pain: A Randomized Controlled Trial. Spine 2007, 32, 1578-1585. [CrossRef] [PubMed]

33. Khan, M.; Akhter, S.; Soomro, R.R.; Ali, S.S. The effectiveness of Cognitive Behavioral Therapy (CBT) with general exercises versus general exercises alone in the management of chronic low back pain. Pak. J. Pharm. Sci. 2014, 27, 1113-1116. [PubMed]

34. Pincus, T.; Anwar, S.; McCracken, L.M.; McGregor, A.; Graham, L.; Collinson, M.; McBeth, J.; Watson, P.; Morley, S.; on behalf of the OBI Trial Management Team; et al. Delivering an Optimised Behavioural Intervention (OBI) to People with Low Back Pain with High Psychological Risk; Results and Lessons Learnt from a Feasibility Randomised Controlled Trial of Contextual Cognitive Behavioural Therapy (CCBT) vs. Physiotherapy. BMC Musculoskelet. Disord. 2015, 16, 147. [CrossRef] [PubMed]

35. Zgierska, A.E.; Burzinski, C.A.; Cox, J.; Kloke, J.; Stegner, A.; Cook, D.B.; Singles, J.; Mirgain, S.; Coe, C.L.; Bačkonja, M. Mindfulness Meditation and Cognitive Behavioral Therapy Intervention Reduces Pain Severity and Sensitivity in Opioid-Treated Chronic Low Back Pain: Pilot Findings from a Randomized Controlled Trial. Pain Med. 2016, 17, 1865-1881. [CrossRef] [PubMed]

36. Linden, M.; Scherbe, S.; Cicholas, B. Randomized controlled trial on the effectiveness of cognitive behavior group therapy in chronic back pain patients. J. Back Musculoskelet. Rehabil. 2014, 27, 563-568. [CrossRef] [PubMed]

37. Basler, H.-D.; Jäkle, C.; Kröner-Herwig, B. Incorporation of cognitive-behavioral treatment into the medical care of chronic low back patients: A controlled randomized study in German pain treatment centers. Patient Educ. Couns. 1997, 31, 113-124. [CrossRef]

38. Linton, S.J.; Andersson, T. Can Chronic Disability Be Prevented?: A Randomized Trial of a Cognitive-Behavior Intervention and Two Forms of Information for Patients With Spinal Pain. Spine 2000, 25, 2825-2831. [CrossRef]

39. Murphy, J.L.; Cordova, M.J.; Dedert, E.A. Cognitive behavioral therapy for chronic pain in veterans: Evidence for clinical effectiveness in a model program. Psychol. Serv. 2020. [CrossRef]

40. Proulx, K. Integrating Mindfulness-Based Stress Reduction. Holist. Nurs. Pract. 2003, 17, 201-208. [CrossRef]

41. Majeed, M.H.; Ali, A.A.; Sudak, D.M. Mindfulness-based interventions for chronic pain: Evidence and applications. Asian J. Psychiatry 2018, 32, 79-83. [CrossRef] [PubMed]

42. Morley, S.; Eccleston, C.; Williams, A. Systematic review and meta-analysis of randomized controlled trials of cognitive behaviour therapy and behaviour therapy for chronic pain in adults, excluding headache. Pain 1999, 80, 1-13. [CrossRef]

43. Hartvigsen, J.; Hancock, M.; Kongsted, A.; Louw, Q.; Ferreira, M.L.; Genevay, S.; Hoy, D.; Karppinen, J.; Pransky, G.; Sieper, J.; et al. What low back pain is and why we need to pay attention. Lancet 2018, 391, 2356-2367. [CrossRef]

44. Wertli, M.M.; Eugster, R.; Held, U.; Steurer, J.; Kofmehl, R.; Weiser, S. Catastrophizing—a prognostic factor for outcome in patients with low back pain: A systematic review. Spine J. 2014, 14, 2639-2657. [CrossRef] [PubMed]

45. Pinheiro, M.B.; Ferreira, M.L.; Refshauge, K.; Maher, C.; Ordoñana, J.R.; Andrade, T.B.; Tsathas, A.; Ferreira, P. Symptoms of depression as a prognostic factor for low back pain: A systematic review. Spine J. 2016, 16, 105-116. [CrossRef] [PubMed]

46. Crofford, L.J. Psychological aspects of chronic musculoskeletal pain. Best Pract. Res. Clin. Rheumatol. 2015, 29, 147-155. [CrossRef] [PubMed]

47. Tagliaferri, S.D.; Miller, C.T.; Owen, P.J.; Mitchell, U.H.; Brisby, H.; FitzGibbon, B.; Masse-Alarie, H.; Van Oosterwijck, J.; Belavy, D.L. Domains of Chronic Low Back Pain and Assessing Treatment Effectiveness: A Clinical Perspective. Pain Pract. 2020, 20, 211-225. [CrossRef] 